tumour necrosis factor or interleukin-1. It would, therefore, be not unlikely to find differentiation affects of IFN- $\beta_{2} / \mathrm{BSF}-2$ on $\mathrm{B}$ cells at concentrations too low to produce antiviral activity on other cells. Contrary to Billiau's comment ${ }^{5}$, this does not mean that the inteferon activity of IFB- $\beta_{2} /$ BSF- 2 is unimportant for its function: as it is as inducible as type I interferons by double-stranded RNA and viruses in many cells ${ }^{2,12}$, IFN- $\beta_{2}$ could provide an important link between the immediate tissue antiviral response and the more delayed antibody production in viral infections.

Michel Revel Asher Zillberstein

Virology Department,

Weizmann Institute of Science,

Rehovot, Israel

1. Hirano, T. et al. Nature 324, 73-76 (1986)

2. Weissenbach, J. et al. Proc. natn. Acad. Sci. U.S.A. 77 $7152-7156(1980)$

3. Zilberstein, A., Ruggieri, R., Korn, J.H. \& Revel, M. EMBO J. 5, 2529-2537 (1986)

4. Revel, M. et al. in The Biology of the Interferon System 1985 (eds Stewart, W.E. \& Schellekens, H.) 207. 216; 119-124 (Elsevier, Amsterdam, 1986).

5. Billiau, A. Nature 324, 415 (1986)

6. Zilberstein, A. et al. in The Biology of the Interferon System 1986 (eds Cantell, K. \& Schellekens, H.) (Nijhoff, Boston, 1986).

7. Zilberstein, A., Ruggieri, R. \& Revel, M. in The Interferon System (eds Rossi, G.B. \& Dianzani, F.) 73. 83 (Raven, New York, 1985).

8. Ostlund, L., Einhorn, S., Robert, K.-H., Juliusson, G. \& Biberfeld, P. Blood 67, 152-159 (1986)

9. Sidman C.L. Marshall, J.D. Shultz) L.D. Gray, P.W. \& Johnson, H.M. Nature 309, 801-804 (1984).

0. Bich-Thuy, L.T. \& Fauci, A.S. J. clin. Invest. 77, 1173 1179 (1986)

11. Wallach, D. Cell. Immun. 75, 390-395 (1983)

12. Kohase, M.,Henriksen-DeStefano, D., May, L.T., Vilcek, J. \& Sehgal, P.B. Cell 45, 659-666 (1986).

\section{Variations in chickens}

SIR-Two recent reports in Nature ${ }^{1,2}$ suggest to us a possible mechanism for the generation of antibody diversity in chickens.

During immunoglobulin light-chain gene rearrangement, recombination occurs at conserved heptamer and nonamer nucleotide sequences which flank each germline variable $(V)$ and joining $(J)$ gene segment. Combinational joining among multiple non-identical $V$ and $J$ segments is a major source of antibody diversity in the mouse and human. In contrast, the principal light-chain locus of the chicken appears to contain only one $J$ and only a single functional $V$ segment, and fusion of this pair is the predominant (if not the only) rearrangement event observed. Other $V$ like elements exist upstream, but those sequenced to date are pseudogenes. Nevertheless, the chicken produces diverse light chains. Diversification appears to occur through transposition of sequences from pseudo- $V$ segments into the rearranged $V / J$ locus. The mechanism of this transposition is not known, but is thought to involve gene conversion ${ }^{3}$.

The finding ${ }^{1,2,4}$ that transcriptionallycompetent heavy-chain genes can undergo secondary rearrangements in which one $V$ segment replaces another, with recombination occurring at a heptamer in the coding sequence of the first $V$ segment, implies that the lymphocyte recombinase system can act on isolated heptamers contained in rearranged immunoglobulin genes. Upon examining the published sequences of the functional light chain $V$ segment and three pseudo- $V$ elements from the chicken, we find that each contains at least two heptamer elements within the coding region; these are located immediately upstream of the second and third complementarity-determining regions. It is unlikely that the pseudo- $V$ loci undergo conventional rearrangements ${ }^{3}$. However, these internal heptamers, coupled with the putative heptamer-binding and endonucleolytic activities of the recombinant system, could serve as efficient sites for synapsis and strand exchange between the functional $V$ segment and $V$ like pseudogenes, much as sequences flanking the mating-type loci of yeast are thought to $\mathrm{do}^{5}$. Resulting gene conversion events would tend to alter precisely those portions of the gene that determine antigen-specificity. Somatic diversification of the chicken light-chain genes might thus occur through a variation of the conventional heptamer-mediated recombinase pathway.

DANiEl CONRAD Tristram G. Parslow

\section{Departments of Pathology and of}

Microbiology and Immunology, University of California,

San Francisco, California 94143, USA

1. Reth, M., Gehrmann, P., Petrac, E. \& Wiese, P. Nature 322, 840-842 (1986)

2. Kleinfield, R. et. al. Nature 322, 843-846 (1986).

3. Reynaud, C. -A., Anquez, V., Dahan, A. \& Weill, J. -C. Cell 40, 283-291 (1985).

4. Beck-Engeser, G. B., Jack, H. -M. \& Wabl, M. Proc. natn. Acad. Sci. U.S.A. (in the press)

5. Strathern, J. N. et al. Cell, 31, 183-192 (1982).

\section{Functions of leaf fall}

SIR-To add to those already put forward $^{1-3}$, may I suggest yet two more functions for leaf fall?

Some leaves may be shed because they cease to be economical in terms of their own and/or the whole plant's energy and nutrient budget. Such shedding would have the additional advantage of allowing a better distribution of light in the plant canopy, while minimizing competition for water and other nutrients from the soil.

It also seems possible that plants may initially produce many more leaves than they require, later shedding those that are in excess of the optimum number for the normal life cycle.

The above proposals gain support from the fact that in many of the economic legume and oil-seed crops, which can experience considerable leaf fall, reproductive structures can play an important role in the overall process of building seed yields, indicating that some leaves, at least, are dispensable $^{4-7}$. The surplus foliage can account for at least half of the total plant foliage $e^{\gamma}$. In fact considerable defoliation of such plants can be carried out, without a significant decrease in seed yields. Thus, in all plants where reproductive structures make a considerable contribution to the final seed yields, shedding of surplus foliage could be economical in the overall metabolic context of the plant and allow better distribution of light, water and nutrients.

\section{Institut de Biologie}

A.S. RAO

et-Physiologie Vegetales,

1015-Université de Lausanne,

Lausanne, Switzerland

1. Ford, B.J. Nature 323, 763 (1986)

2. Hardwick, R.C. Nature 324, 517 (1986)

Hendry, G. Nature 325, 22, (1987)

Crookston, R.K., O'toole, J \& Ozbun, J.L. Crop Sci. 14 $708(1974)$.

5. Hardwick, R.C. Br. Pl. Growth Regulator Group Monogr. 9, 61-74 (1983).

6. Luthra, Y.P., Sheoran, I.S. \& Singh, R. Photosynthetica 17 , $210(1983)$.

Willmer, C.M. \& Johnston, W.R. Planta 130, 33 (1976).

. Allen, E.J., Morgan, D.G. \& Ridgman, W.J. J. agric. Sci. Camb. 77, $339(1971)$

\section{Body temperature of homoiothermic animals}

SIR-I agree with Calder ${ }^{1}$ and Dunitz and Benner ${ }^{2}$ that $\mathrm{Paul}^{3}$ is wrong to suppose that the body temperature of many homoiothermic animals is $36^{\circ} \mathrm{C}$ because that is approximately the temperature of minimum specific heat of water. Rather it may produce a paradox - homoiothermic animals live at the temperature of maximum thermal fluctuations. I also agree with Dunitz and Benner when they assert that biological water is not pure water but I disagree with them when they use the data of pure water to solve the paradox.

Indeed, water in biosystems must be thought of as adsorbed onto macromolecules, either in a localized or mobile form $^{4.5}$. Without additional hypotheses, this model explains the $\mathrm{Na}^{+} / \mathrm{K}^{+}$ratio $^{6.7}$, the anaesthetic effect of inert gases ${ }^{8}$ and the anomalously high viscosity of water in the celli ${ }^{4}$; therefore, it must be considered as a plausible model for water in biosystems.

The observation that the specific heat of water in biosystems such as normal blood plasma and haematopoietic cells is lower ( $6 \%$ and $11 \%$, respectively) than that of pure water, shows that in biological water some degrees of freedom can be excited with more difficulty than in pure water, thus sustaining the adsorbed water model.

G.F. CEROFOLINI

SGS Microelectronica, 20041 Agrate MI, Italy

1. Calder, W.A. Nature 324, 418 (1986)

. Dunitz, J.D. \& Benner, S.A. Nature 324, 418 (1986)

3. Paul, J. Nature 323, 300 (1986)

4. Cerofolini, G.F. \& Cerofolini, M. Specul. Sci. Technol. 3, $149(1980)$

Cerofolini, G.F. Adv. Colloid Interface Sci. 19, 103 (1983)

6. Wiggins, P.M. J. theor. Biol. 32, 131 (1971).

Cerofolini. G.F. Nuovo Cimento D2. 763 (1983).

8. Cerofolini, G. F. Nuovo Cimento D2, 1156 (1983). 